\title{
Geography and Citizenship Education in Hong Kong
}

\author{
Tammy Kwan \\ University of Hong Kong , Pokfulam Road, Hong Kong
}

Elsewhere (Kwan, 2002), I have written about the teaching of geographical knowledge and skills as two easily taught explicit aspects of the subject, with the values aspect of the syllabus often seen by teachers as too subtle to handle. Although values education is always included in syllabuses, its very nature of being difficult to teach and assess often leads teachers to pay only lip service to its actual teaching. Yet I believe it is values education that has the most profound effect on students' personal development. The problem is that such learning and development is not detected easily or immediately within the classroom, and its long-lasting effects may only be evident much later in time when the students have grown up to act upon what they have learned, believing it to be useful, meaningful and important.

I also encouraged geography teachers (at least in Hong Kong) to take advantage of syllabus revision and curriculum reform, to bring this subtle hidden element of values education upfront by highlighting the necessity to bring about better cultural understanding in students. This refers to both understanding their own culture and becoming a sympathiser and empathiser with cultures other than their own. Through such deliberation, we stand a better chance of preparing geography students to become responsible and committed global citizens beyond the four walls of the classroom.

There is no doubt that geography has a significant and uniquely supportive role to play in preparing students to become responsible citizens. The question is how to achieve this generic goal of citizenship education through geographical education. Porter (1991) described citizenship education in three aspects:

- Citizenship as status, which means the relationship between the individual and the state.

- Citizenship as volition which refers to feelings of togetherness, community, culture and history.

- Citizenship as competence, which expects active, involved participation in debate and decision making.

Gilbert (1996) considered citizenship to be a contested term, which ranges from personal right to national loyalty. He described four major approaches used to illustrate this 'complicated' concept:

- Citizenship as a status implying formal rights and duties (the broad range of entitlements and obligations), which accrue to the status of citizen. 
- Citizenship as an identity and a set of moral and social virtues based in the democratic ideal.

- Citizenship as a public practice conducted through legal and political processes.

- Citizenship as participation in decision making in all aspects of life which emphasises the practice of democratic rights in making decisions across a range of sites at home, school, community, nation and the world.

The Center for Citizenship Education (CCE) of the Hong Kong Institute of Education adopted the notion of 'Multidimensional Citizenship' suggested by Cogan and Derricott (2000) to embrace the broader meaning of citizenship. They analyzed citizenship from the perspective of four interconnected dimensions: the personal, the social, the spatial and the temporal. These four dimensions of multidimensional citizenship provide a range of perspectives, an analytic prism or typology, through which one can study how citizenship is examined, evaluated and practised in a comprehensive fashion.

To give depth to the conceptualisation of multidimensional citizenship, CCE further drew upon three internationally established academic and educational traditions within the field of citizenship education. They are values, civics and environmental education. This is similar to Gilbert's (1996: 111-13) three approaches to education for citizenship, which are environmental education, cultural studies and the nature of identity. They are essentially the popular cross-curricular themes that infuse various humanities subjects. Environmental education apparently has a special link with geographical education and also, to a large extent, cultural aspects.

With these three frameworks in mind, I will further describe how geography in Hong Kong can and/or should bring about stronger citizenship education in particular during the unique transitional political environment before and after the return of sovereignty to China in 1997 . This also coincides with the advocacy of educational reform through curriculum restructuring (Education Commission, 2000).

The general school curriculum of the pre-handover period was essentially a traditional subject-oriented academic curriculum. Though the notion of comprehensive education was promoted in the mid 1970s via mandatory nine-year compulsory education, the ideological perspective (Heater, 1990) was basically conservative and elitist with the prime intention of producing a small group of bright, smart and loyal civil servants to serve the Government. But as 1997 was approaching, there were clear signs to encourage school-based curriculum development in which the 'Chinese elements' were highlighted and increased through strengthening the civics education component as one of the cross curricular themes in the form of permeation into existing subjects. Even more so, there was the introduction of 'Civics Education' into the junior secondary school curriculum to help students to strengthen their understanding of nationhood and sense of belonging, which would lead to the building up of a national identity. On the other hand, environmental education, as another major crosscurricular theme, is still to be infused into other subject curriculums, especially to geography and biology (CDC, 1999).

When the first Government of the Hong Kong Special Administrative Region (HKSAR) outlined its plan for education on 1 July 1997, one of the major six goals 
identified was 'to promote the teaching of Chinese culture and heritage and to strengthen civic education' (Morris et al., 2000: 249).

In 2000, the Education Department of Hong Kong consolidated the proposal of an education reform (Education Commission, 2000) to develop a new culture of teaching and learning that could bring about real changes in school life to students. This involves shifting from:

- transmission of knowledge to learning how to learn;

- over-emphasising academic studies to focusing on whole-person development;

- compartmentalised learning to integrated learning;

- textbook focus to the use of diversified teaching and learning materials;

- classroom learning to seeking support from the community to enhance learning;

- traditional timetabling to a flexible arrangement of learning time; and

- premature streaming to providing more opportunities for students to explore their aptitudes and potential.

Morris et al. (2000: 244) discussed the interlinked features of Hong Kong education, namely the educational policy-making process and the conception of citizenship promoted through various subjects in the school curriculum in this era of change. They believed the features have been affected by the Hong Kong SAR Government's attempts to both establish its legitimacy and maintain a high degree of stability following the transfer of sovereignty. They used Heater's five ideological perspectives (Heater, 1990: 213) of:

- participatory/democratic;

- conservative/elitist;

- totalitarian/manipulative ;

- nationalist/integrative ;

- universalist/global.

as a framework for locating shifts in the form of civic participation promoted by the state, especially within those areas of the school curriculum, which explicitly promote conceptions of citizenship such as civic education, social studies and history (p. 244). Further, Morris and Chan (1997: 104) considered changes to the content of existing subjects such as history, Chinese (history and language) and economic and public affairs to promote a greater awareness of China, Chinese culture and political institutions. There was also the mentioning of new subjects designed to focus on a range of local issues and controversies. To my surprise, there was no mention of geography at all in terms of any degree of contribution to this aspect. Was it purely an unintentional oversight or was it a deliberate indication to reflect the state of mind of the above-mentioned authors that geography is not seen as an important school subject to promote citizenship?

From this brief description of chronological change prior, during and after the 1997 handover, and referring back to Heater's five political ideological perspectives, one can generalise broadly that the Hong Kong curriculum is moving from conservative/elitist to nationalist/integrative.

As a result, all these new expectations of educational reform advocatea change of direction. It changes from a content-based conventional curriculum to one that 
promotes students' active learning skills and construction of knowledge through issue-based inquiry learning which accompanies the development of lifelong positive values and attitudes. Instead of having the school curriculum organised around academic subjects, eight key learning areas have been identified to form the framework of study. They are:

- Chinese Language Education;

- English Language Education;

- Mathematics Education;

- Science Education;

- Technology Education;

- Personal, Social and Humanities Education (PSHE);

- Arts Education;

- Physical Education.

Among these eight key learning areas, geography, which used to be a classical subject within the humanities area, is now placed within the Personal, Social and Humanities Education (PSHE) key learning area. With this new framework of educational curriculum establishment, teachers and students are henceforth also expected to perform quite differently in the teaching and learning process. In general, teachers are expected to play the role of an informed facilitator while students are trained to be self-directed learners who are empowered to learn throughout their lifelong learning time span to become informed responsible citizens.

Appendix 1 outlines the teaching structure of the PSHE key learning area in which geographical education has a part to play. There are six strands chosen to reflect the new educational aims of Hong Kong Education. Sub-strands are listed with contribution by relevant subjects or cross-curricular perspectives. Appendix 2 highlights the strand of 'social system and citizenship' with the breakdown of objectives in the three domain areas across the four key stages of education (i.e. lower and upper primary, junior and senior secondary). It is within this arena that all humanities subjects, including geography, are seen to have a substantial and important role to play to help students to acquire and strengthen the concept of citizenship, and have them committed to act like responsible citizens in various local, national and global contexts.

Morris et al. (2000: 255) summarised the traditional Chinese values as embedded in various public speeches made by key people such as the Chief Executive since the 1997 handover. These Chinese values are:

- the avoidance of confrontation;

- a focus on the obligations and responsibilities of individuals towards community and the country;

- moral 'correctness'; and

- an emphasis on societal values.

As a result, they see that Chinese culture and values are portrayed as a homogeneous and monolithic entity, associated with a desirable range of values such as sense of unity, consensuality, modesty and integrity.

Referring to Porter's framework of citizenship, Morris et al. (2000: 259) considered school curriculum prior to 1997 emphasising the 'status' aspect of 
citizenship, whereas the introduction of civics education as a school subject implies strengthening citizenship as a form of 'volition'. Nevertheless, they considered the aspect of 'competence' continues to be neglected or unmentioned. If Gilbert's framework is used, then accordingly, they may see 'status' and 'identity' being highlighted at the expense of 'public practice' and 'participation'. It appears that Morris et al. (2000) made their comments based on the subjects of history, civic education and economic and public affairs.

However, I believe that geography can be considered an appropriate subject site to promote aspects of 'competence' according to Porter and 'participation' according to Gilbert. This is especially the case if we agree that geography is the subject that works closely with the cross-curricular theme of environmental education. Through relevant inquiry into geographical and environmental issues, students are prepared to take action and other relevant participation in conserving the environment and sustainable development. In a sense, they are cultivated to take up responsibility (even it is only through minute contributions from an individual) to lead the community and the environment. In this, there is the strong belief that geography can do a substantial part in these two aspects of 'competence' and 'participation'.

This is particularly the case when the Hong Kong S1-3 geography syllabus (CDC, 1998) and the upcoming revised S4-5 geography syllabus (CDC, 2002) both emphasise of the use of inquiry approaches to geographical issues which to a large extent are heavily linked to environmental issues. The introduction section of the S4-5 syllabus (CDC, 2002: 1) states clearly, 'On the whole, through inquiry of issues, geographical education provides students with the essential learning experiences in relation to the individual, the human society and the environment.' This intention is further made explicit in the objective statements of the values and attitude domain that students upon completion of the S1-5 geography syllabus should be able to:

- show interest in various natural and human characteristics;

- appreciate the beauty of nature and the different living conditions of people;

- be aware of environmental limitations and problems and take appropriate action to promote sustainable development;

- cultivate a sense of belonging to their society and nation;

- show respect for all peoples, their cultures, values and ways of life; and

- be aware of the increasing global interdependence of peoples and nations, and understand the importance of international solidarity and cooperation.

It is in this context that we have confidence that geography education in Hong Kong schools can play a significant role in helping students to develop 'competence' in citizenship to practise and to care for the environment, in order to perform a stewardship role in the era of educational change and curriculum reform despite Hong Kong's political change of sovereignty in 1997.

\section{Correspondence}

Any correspondence should be directed to Dr Tammy Kwan, Associate Professor, Faculty of Education (Geographical Education), The University of Hong Kong, Pokfulam Road, Hong Kong (tylkwan@hkucc.hku.hk). 


\section{References}

Cogan, J. and Derricott, R. (2000) Citizenship for the 21stcentury: An International Perspective on Education. London: Kogan Page.

Curriculum Development Council (1998) Syllabus for Secondary Schools: Geography (Secondary 1-3). Hong Kong: Education Department.

Curriculum Development Council (1999) Guidelines on Environmental Education in Schools. Hong Kong: Education Department.

Curriculum Development Council (2000) Learning to Learn: Personal, Social and Humanities Education (Consultation Document), p. 15.

Curriculum Development Council (2002) Revised secondary 4-5 geography syllabus (draft). Hong Kong: Education Department.

Education Commission (2000) Review of Education System: Reform Proposals. Education Blueprint for the 21st Century. Hong Kong Special Administrative Region of the People's Republic of China.

Gilbert, R. (1996) Education for active and informed citizenship. In R. Gilbert (ed.) Studying Society and Environment: A Handbook for Teachers. Melbourne: Macmillan.

Heater, D.B. (1990) Citizenship: The Civic Ideal in World History, Politics and Education. London: Longman.

Kwan, T. (2002) Geography beyond the classroom: Achieving cultural understanding through issue-based inquiry learning. In R. Gerber and M. Williams (eds) Geography, Culture and Education. Dordrecht: Kluwer Academic.

Morris, P. and Chan, K.K. (1997) The Hong Kong school curriculum and the political transition: Politicisation, contextualization and symbolic action. In M. Bray and W.O. Lee (eds) Educational and Political Transition: Implications of Hong Kong's Change of Sovereignty (pp. 101-18). Comparative Education Research Centre: University of Hong Kong.

Morris, P., Kan, F. and Morris, E. (2000) Education, civic participation and identity: Continuity and change in Hong Kong. Cambridge Journal of Education 30 (2), 243-62.

Porter, A. (1991) Political literacy. In D. Heater and J.A. Gillespie (eds) Political Education in Flux. London: Sage. 


\section{Appendix 1}

The conceptual development of PSHE, including the six strands and their sub-strands to enhance lifelong learning

\begin{tabular}{|c|c|c|c|}
\hline \multicolumn{2}{|c|}{ Strands } & \multirow{2}{*}{ 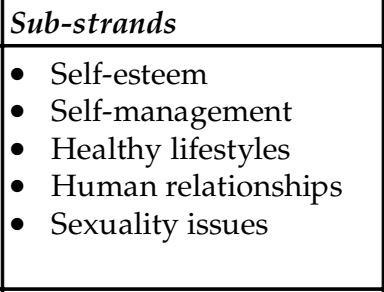 } & \multirow[b]{2}{*}{\begin{tabular}{|l} 
Perspective \\
To understand people as individuals \\
(This strand integrates content and \\
learning outcomes across the subject \\
areas of Personal and Social \\
Education, Civic Education and \\
Religious and Ethical Education) \\
\end{tabular}} \\
\hline & $\begin{array}{l}\text { Personal and } \\
\text { Social } \\
\text { Development }\end{array}$ & & \\
\hline II & $\begin{array}{l}\text { Time, } \\
\text { Continuity } \\
\text { and Change }\end{array}$ & $\begin{array}{l}\text { - Time and chronology } \\
\text { - Understanding the } \\
\text { past } \\
\text { - Change and continuity } \\
\text { - Interpretations and } \\
\text { perspectives }\end{array}$ & $\begin{array}{l}\text { To understand people in relation to } \\
\text { time } \\
\text { (This strand integrates content and } \\
\text { learning outcomes across the subject } \\
\text { areas of Chinese History and History) }\end{array}$ \\
\hline III & $\begin{array}{l}\text { Culture and } \\
\text { Heritage }\end{array}$ & $\begin{array}{l}\text { - Foundation of culture } \\
\text { - Customs and } \\
\text { traditions } \\
\text { - Modernization and the } \\
\text { post modern world } \\
\text { Cultural diversities } \\
\text { and interaction } \\
\end{array}$ & $\begin{array}{l}\text { To understand people in the cultural } \\
\text { world } \\
\text { (This strand integrates content and } \\
\text { learning outcomes across the subject } \\
\text { areas of Chinese History, History, } \\
\text { Ethics and Religious Studies and } \\
\text { Travel and Tourism) }\end{array}$ \\
\hline & $\begin{array}{l}\text { Place and } \\
\text { Environment }\end{array}$ & $\begin{array}{l}\text { - Natural and human } \\
\text { features of a place } \\
\text { - Spatial association and } \\
\text { interaction } \\
\text { - People-environment } \\
\text { interrelationships } \\
\text { - Conservation and } \\
\text { sustainable } \\
\text { development } \\
\end{array}$ & $\begin{array}{l}\text { To understand people in relation to } \\
\text { space and the environment } \\
\text { (This strand integrates content and } \\
\text { learning outcomes across the subject } \\
\text { areas of Geography, Environmental } \\
\text { Education and Travel and Tourism) }\end{array}$ \\
\hline V & $\begin{array}{l}\text { Resources } \\
\text { and } \\
\text { Economic } \\
\text { Activities }\end{array}$ & $\begin{array}{l}\text { - Use of resources } \\
\text { - Production and } \\
\text { consumption } \\
\text { - People and work } \\
\text { - Exchange }\end{array}$ & $\begin{array}{l}\text { To understand people in the material } \\
\text { world } \\
\text { (This strand integrates content and } \\
\text { learning outcomes across the subject } \\
\text { areas of Economics, Geography, } \\
\text { Government and Public Affairs and } \\
\text { Travel and Tourism) }\end{array}$ \\
\hline VI & $\begin{array}{l}\text { Social } \\
\text { Systems and } \\
\text { Citizenship }\end{array}$ & $\begin{array}{l}\text { - } \begin{array}{l}\text { Rights, responsibilitie } \\
\text { and social virtues }\end{array} \\
\text { - Social norms, rules and } \\
\text { law } \\
\text { - Local, national and } \\
\text { global identities } \\
\text { - Social system, political } \\
\text { system and interaction }\end{array}$ & $\begin{array}{l}\text { To understand people as groups } \\
\text { (This strand integrates content and } \\
\text { learning outcomes across the subject } \\
\text { areas of Civic Education, Government } \\
\text { and Public Affairs and Ethics and } \\
\text { Religious Studies) }\end{array}$ \\
\hline
\end{tabular}

Source: Curriculum Development Council (2000) Learning to Learn: Personal, Social and Humanities Education (Consultation Document), page 15. 


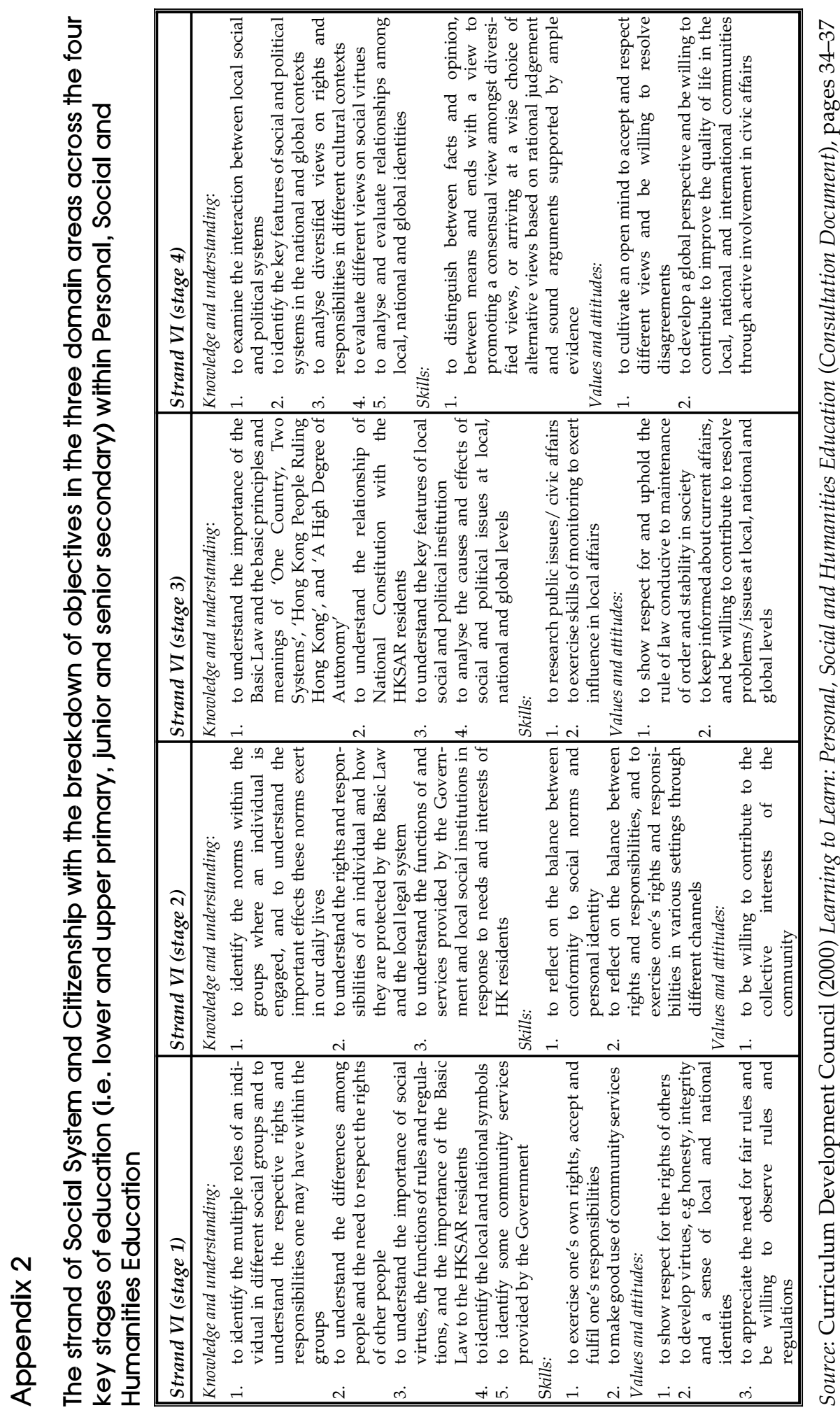

